\title{
EMPLOYMENT AND SMEs DURING CRISES
}

\begin{abstract}
The current economic crisis has raised concerns about the persistent increasing duration of unemployment. Although lay-offs at large firms normally make headlines during crises, we still know little about the potential impact of firm size on firms' adjustment behavior under a crisis context. We study firm size effects on employment growth during economic slowdowns, using a rich microeconomic database for the 1988-2007 period in the Portuguese manufacturing industry. The results show that economic downturns impacted negatively upon firm growth. This negative impact is found to be higher for larger firms, either during or also immediately after crisis periods. Small and medium sized enterprises (SMEs) emerge as potential stabilizers in downturn periods. However, larger firms seem to be able to quickly recover from downturn periods.

Our results contribute to the scarce literature on these matters and also to the understanding of the Portuguese case, where there are a great number of SMEs which secure the majority of jobs. These first results may be useful as SMEs play a determinant role in other economies of the European Union (EU).
\end{abstract}

Keywords: employment; firm growth; SMEs; economic slowdowns; Portugal.

JEL Codes: D21, E32, J21, L25, L60 


\section{INTRODUCTION ${ }^{1}$}

Understanding the determinants of firm growth has long been a key goal of research in different fields (Coad 2009; Short et al. 2009). However, we still know little about the importance of firm and industry-level determinants for firms' adjustment under a crisis context.

Differences between groups based on size have been deeply investigated because firm size may substantially influence firm performance and growth (Hawawini et al. 2003; Coad 2009; Short et al. 2009). The literature has extensively studied the relationship between firm size and firm growth, mainly aiming at establishing or refuting the empirical validity of the Law of Proportional Effect, often known as Gibrat's Law. However, the effect of size upon firm growth measured during downturns has been scarcely investigated. While losses and lay-offs at large firms normally make the headlines during periods of crisis, many SMEs may also be severely affected by economic slowdowns. Weak demand, tight credit and strong dependence from few customers and suppliers are the chief pressures faced by these enterprises during periods of economic downturn. Nonetheless, it is not clear if size affects growth during economic slowdowns.

In this paper we aim to fill this gap by considering to what extent firm size is a determinant for firm growth during periods of economic downturn, and also explore other firm and industry-level variables that, according to the literature, are likely to impact significantly on firm growth patterns overall. We use data from the Quadros de Pessoal ${ }^{2}$ database, a rich and comprehensive dataset covering all firms with wage earners in Portugal, a country for which there is no study addressing this theme. The study covers the period 1988-2007, including two periods of economic downturn (1991-1993 and 20012003). These were marked by significant declines in real gross domestic product (GDP) growth, considerable increases in unemployment rates and also evident breaks in private consumption and investment (Bank of Portugal 2009a, 2009b). According to the data from the Bank of Portugal, the Portuguese real GDP growth dropped from a rate of $4.4 \%$ in 1991 to $-2 \%$ in 1993. Similarly, the growth rate of Portuguese GDP has fallen from $2 \%$ in 2001 to $-0.8 \%$ in 2003. During these periods, unemployment growth rates suffered an increase of 1.3 and 2.3 percentage points, respectively. Both downturns were to some extent an effect of a decline in economic activity of developed countries, which led to considerable reductions in Portuguese exports and then in private consumption and investment.

To the best of our knowledge, this is the first in-depth study addressing this question benefitting from the availability of a long and rich database with microeconomic data. Our results contribute not only to the scarce literature on these matters, but also to the understanding of the Portuguese case, where SMEs assume great positions in number, securing the majority of jobs. Understanding this topic in the Portuguese context is particularly useful because, as in Portugal, small and medium firms employ more than half of the labor force in the private sector of the OECD area and account for over 99\% of all enterprises in the EU (OECD 2009). The ability of countries to promote the sustainability of these enterprises may arise as a great contribution to the revival of the global economy, as well as the recovery of individual national economies. By understanding better the role and differentiated behavior of firms

\footnotetext{
${ }^{1}$ We acknowledge the support from the Portuguese Fundação para a Ciência e Tecnologia (FCT) [SFRH/S=BSAB/ 920/2009].

${ }^{2}$ We acknowledge GEP - MTSS for allowing the use of the original data. The data analysis, results and conclusions are the authors' own responsibility.
} 
according to their size, governments may improve policy action. Obviously the current financial and economic crisis that has resulted in the worst global recession since World War II promoted us to the present investigation. In our study we focus on past economic slowdowns. However, results from past events may be of value in understanding more modern recessions, such as the one from which the world economy is currently recovering.

The remainder of this paper is structured as follows: in section 2 we review the background literature on this matter and derive our research questions; in section 3 we present the empirical analysis and discuss the results; section 4 concludes and raises some policy implications.

\section{FIRM SIZE, FIRM GROWTH AND ECONOMIC DOWNTURNS}

Despite the wide theoretical and empirical discussions on the relationship between firm size and firm growth, a topic raised early by Gibrat (1931) with the enduringly debated Law of Proportional Effect ${ }^{3}$, we still know little about this relationship under a crisis environment. The empirical evidence on this matter is not only small in number but also limited by the crises' contexts hitherto studied, regarding the strong focus on the Asian financial crisis in 1997. The results are also mixed and inconclusive.

In the literature, we find valid reasons for why small firms may have a differential impact relative to larger firms. Smaller enterprises may be more flexible in adapting to an economic downturn as they are less resistant to inertia, rigidity and sunk costs (Tan and See 2004), more able to exploit market niches (Gregory et al. 2002; Narjoko and Hill 2007; Hodorogel 2009), being concentrated on activities characterized by economies of agglomeration, rather than economies of scale (Berry et al. 2001; Hall and Harvie 2003), and less reliant on formal credits compared to their larger counterparts, who are more burdened by debts (Sato 2000; Wangel and Rodriguez 2006). Even their disadvantages at technological and knowledge levels can be overcome through the imitation of other firms' best practices (Nugent and Yhee 2002). As a result, SMEs may be more able to sustain their employment levels and thus counteract the negative effects of the crisis, helping to stabilize the economy. Indeed, there is robust empirical evidence showing that SMEs, and specifically export-oriented SMEs, are better able to adjust to crises (e.g., Sato 2000; Berry et al. 2001; and Wengel and Rodriguez 2006 for Indonesia; Gregory et al. 2002 for Korea; Tan and See 2004 for Singapore; and Régnier 2005 for Thailand; all in the context of the 1997 Asian financial crisis).

There are also several reasons to expect smaller firms to be more vulnerable to the negative effects of an economic crisis. On the one hand, SMEs may suffer disproportionately from economic downturns due to their limited financial resources and dependence on banks' lending, paying for such high interest rates (e.g. Mulhern 1996 for the crisis of 1989-1994 in Venezuela; Domaç and Ferri 1999 for the 1997 Asian financial crisis; and Özar et al. 2008 for the 2001 Turkish financial crisis). Adding to the financial aspect, their relative shortcomings in terms of technological, managerial and human capabilities may reduce their capacity to overcome the economic crisis (Gertler and Gilchrist 1994;

${ }^{3}$ According to this Law, also known as Gibrat's Law, the rate of firm growth is independent of its past size and growth trajectory (i.e., there are no firm-level scale effects). This means that the vast majority of firms in the market are small and medium sized and that most employees in the industry are concentrated in just a few firms (Sutton 1997). 
Forbes 2002; Beck et al. 2005; Butler and Sullivan 2005; Régnier 2005; Marino et al. 2008; Das and Pradhan 2009). On the other hand, their greater dependence on (fewer) customers and suppliers (Nugent and Yhee 2002) and markets (Butler and Sullivan 2005; Narjoko and Hill 2007; OECD 2009) may lead to increased difficulties in maintaining their activity level in the face of the crisis.

In a third set of studies, firm size has also been found to be insignificant in differentiating firms' performance once other firm or industry variables are controlled for (Claessens et al. 2000; Larsen and Bjerkeland 2005; Forbes 2002). In Table 1, we provide a synopsis on the empirical relationship between firm size and firm performance under crisis events.

***Table 1 about here $* * *$

\subsection{Research question and hypothesis}

The overall state of the economy has long been indicated as an important force driving the growth prospectus of firms. Downturn periods are expected to impact negatively on firms' growth. However, firm and industry characteristics may affect firms' adjustment under a crisis context. Firm size is one of the most debated factors in the growth literature and several studies have found that overall firm size positively influences growth and we may expect this to also be so during economic downturns. Compared to small firms, large firms have more probability of being operated at a minimum efficient scale and may also have better capabilities in terms of human capital and access to capital or markets which in turn improve their chances in the face of economic downturns. Hence, we empirically assess whether size is also a determinant of firm employment growth during economic downturns, having as a main hypothesis under study:

Hypothesis 1) Small and medium firms' growth is more negatively affected by crises.

There are other firm and industry level characteristics clearly associated with firm size which are likely to affect the growth of firms. In our analysis we must properly account for them, in order to investigate if there remain any significant differences in growth that can be attributed to size per se.

\subsection{Control variables}

Firm age is generally acknowledged as one important determinant for firm growth and performance (Coad 2009). We may expect younger firms to grow more, although the relationship might be non-linear.

Firm performance is considered in the literature as an important factor to explain employment growth. It is perhaps quite natural to assume that the most productive firms will grow while the least productive will decrease in size. However, this assumption does not seem to be borne out by empirical work. One explanation for this is that while some firms become more productive through expansion, 
others become more productive through downsizing. Human capital stocks may also be a factor associated with a firm's competitive advantage and thus with its growth prospects, acting as a specific asset that can constitute an ownership advantage for firms. Empirical evidence on the relationship between firm growth and human capital is scarce. Regarding human capital, while, for instance, Almus (2002) identifies a positive effect of qualified workers on the growth of German firms, Robson and Bennett (2000) fail to find a significant effect of skill levels for UK firms' growth. In spite of this, assuming that better skilled workers are more productive than their low-skilled counterparts, we can expect human capital intensity to act as an enhancing factor of firms' growth.

Firms with foreign participation have been found to differ systematically from domestic firms and therefore firm ownership should be accounted for, as foreign firms have often been found to be larger than domestic ones. Regarding the effects of foreign ownership, the results are not however unanimous (e.g., Varum and Rocha 2010; Özler and Taymaz 2004; Girma and Gong 2008; Karlsson et al. 2009).

Firm location in urban centers may also impact upon firm growth, due to urbanization externalities and agglomeration economies (Guimarães et al. 2000). Urban locations often contain a wealth of diverse resources but firms at these locations may also face greater competition and higher costs related to diseconomies of agglomeration (Stearns et al. 1995; Fotopoulos and Louri 2000; Littunen 2000).

Industry attributes shall also be accounted for because firms in different sectors have different probabilities of increasing in size. Industry minimum efficient scale, industry concentration, industry growth, industry agglomeration, export intensity and foreign presence are the main industry-level variables commonly found in the literature to influence firm growth over time (e.g., Audretsch 1995; Barbosa and Louri 2005; Álvarez and Görg 2007; Cardoso 2008; Coad 2009). Firms in industries with higher minimum efficient scale (MES) may grow more in order to reach the necessary scale, while firms in highly concentrated industries may be more stable in terms of size. Regarding agglomeration, this may contribute to firm growth through the creation of externalities between firms. The degree of export intensity and the degree of presence of foreign firms in the industry where a firm operates may impact upon its growth. Greater exposure to international competition may be closed associated to size, but it may also limit the growth prospectus of the firm (Coad 2009).

Hence, along with the sector where the firm operates, these industry characteristics will be taken into account as well, although no definite expectation about their impact exists according to the available literature but they are commonly controlled for in studies of firm growth. 


\section{EMPIRICAL ANALYSIS}

\subsection{Data, methodology and variables}

The study uses data from Quadros de Pessoal (QP), a database from Gabinete de Estratégia e Planeamento (GEP) of the Ministry of Labour and Social Solidarity ${ }^{4}$ that is based on a compulsory annual survey conducted since 1982, covering all firms with wage earners in Portugal. We worked with the original raw data files at the firm-level, which include over 100,000 firms each year. In addition to the QP database, we have also used data on exports from the National Institute of Statistics, as well as on the Gross Value Added from the Bank of Portugal, both at two-digit industry-level (ISIC rev. 2). As we only have data on industries' exports since 1988, our empirical analysis focuses on the period 1988-2007.

Our main aim with this empirical study is to assess the importance of firm size overall, during and immediately after crises. Accordingly, we have first estimated equation 1 for all firms operating in the Portuguese manufacturing industry, with the aim to assess the potential impact of firm size during economic slowdowns:

$\ln \left(Y_{i t}\right)-\ln \left(Y_{i t-1}\right)=\alpha_{i}+Z_{i t}^{\prime} \delta+\gamma_{1}$ Down $+\gamma_{2}$ Size $_{i t}^{*}$ Down $+\varepsilon_{i t}$

where the dependent variable corresponds to the employment growth rate at the firm level ${ }^{5}$, measured by the difference between the employment of firm $i$ in $t$ and in $t-1$, in log terms. In order to evaluate whether the effect of firm size changes during the recovery from a recession, that is, throughout the years immediately following the downturn years, we have estimated a second version of equation (1), where Lagged_Down refers to the downturn dummy previously considered, now evaluated with one, two and three-year lags, in three independent specifications:

$\ln \left(Y_{i t}\right)-\ln \left(Y_{i t-1}\right)=\alpha_{i}+Z_{i t}^{\prime} \delta+\gamma_{1}$ Lagged_Down $+\gamma_{2}$ Size $_{i t} *$ Lagged_Down $+\varepsilon_{i t}$

The vector $Z$ includes those firm and industry characteristics which are likely to affect the dependent variable. We considered size, measured by the natural logarithm of the number of employees, and other variables which, according to the literature, are likely to affect firm growth, and along which small and large firms systematically differ (Coad 2009). In addition to size we considered age, firm performance, ownership, and human capital. Firm location and industry's specificities are also included. The overall effect of the economic downturns (the current effect in the first equation and the lagged effect in the second equation) is given by $\gamma_{1}$ which is expected to be negative. Central to our analysis, the equations also evaluate the importance of firm size during and after downturns through the interaction

\footnotetext{
${ }^{4}$ We acknowledge GEP from the Portuguese Ministry of Labour and Social Solidarity (MTSS) for allowing the use of the original data. The data analysis, results and conclusions are the authors' own responsibility.

${ }^{5}$ Özar et al. (2008) argue that employment-based empirical studies are preferable and more reliable when considering enterprise growth. In opposition, firm growth based on sales or profit data may lead to measurement errors.
} 
terms: Size $_{i t} *$ Down and Size $_{i t} *$ Lagged_Down, respectively. The parameter $\gamma_{2}$ will thus show how significant the differences in employment growth of firms are with different sizes during and after economic slowdowns.

In order to give more robustness to our results, we repeated the above analysis for the separate groups of SMEs and Large Enterprises (LEs), by running the models (1) and (2) without the interaction variable. This allows us to better disentangle the current and lagged effects of downturn periods in firms with different operation scales. We classified firms as SMEs following the European Commission (EC) definition of SMEs (European Commission 2005).

We applied panel data models ${ }^{6}$ with robust standard errors in our estimations and, specifically, the suitability of within-groups and between-groups estimators. For all the estimations, Hausman test rejected the hypothesis of null covariance between the regressors and the individual effects, thus fixed effect estimators proved to be the most appropriate, being unbiased, consistent and asymptotical normal. In addition, our estimations were always applied to all firms in operation every year. Although many empirical studies often select a sample of only surviving firms, such a choice may bias the results in favour of firms with better survival prospects (e.g., Álvarez and Görg 2007). To avoid such a bias, we included in our estimations surviving and non-surviving firms during the period under analysis, which constituted an unbalanced panel. Estimations using a fixed-effects approach take this factor into account, so it does not represent a problem (Greene 2008).

SMEs represent the vast majority of the enterprises in Europe (over $99 \%$ for the EU-27), account for the largest share of employment (67\%) and for over half of the value-added in the EU-27 (Appendix B). They are considered to be the backbone of the European economy and essential for employment and growth. ${ }^{7}$ Consequently, the EC's new approach provides a single coherent policy framework for EU actions in favour of SMEs (Teruel-Carrizosa 2010).

In addition to the Czech Republic and Italy, Portugal is one of the European countries with the highest share of private employment represented by SMEs (over 80\%) (Appendix B). The interest in the Portuguese case is intensified by the particular profile that SMEs seem to present. Portugal (as well as Italy) is a country where SMEs start small and grow very little over time, being mainly found in sectors with small growth opportunities and being, more often than in other countries, organized on the basis of the family. However, Portugal was one of the European countries that experienced higher growth rates of SMEs during the last decade, providing an interesting framework to empirically explore (Erixon 2009).

\section{***Figure 1 about here ${ }^{* * *}$}

Considering Portugal in particular, the significance of SMEs on the overall economy is replicated when considering the manufacturing sector only. The two panels in Figure 1 illustrate the relative importance of SMEs in the total number of firms and total employment of the Portuguese manufacturing industry. Our data shows that, in 1988, SMEs represented $98 \%$ of total manufacturing

\footnotetext{
${ }^{6}$ Panel data models allow us to assess firm growth measures longitudinally, rather than cross-sectionally. The literature points that cross-sectional measurement of firm performance is insufficient and that it should be measured longitudinally, due to the importance of time the dimension (e.g., Pfaffermayr and Bellak 2002; Hult et al. 2008).

${ }^{7}$ Eurostat - Statistics in focus $(31 / 2008)$ - Industry, Trade and Services
} 
firms, accounting for $64 \%$ of total employment. Two decades later, the shares of SMEs were respectively $99 \%$ and $79 \%$. As we can observe, there is a long-term trend towards a greater share of SMEs in the number of enterprises and employment, which justifies the increasing concern of government with the SME sector.

In order to have a first impression of the effects of downturns in firms' employment growth and the relationship between firm size and firm growth, we have depicted the evolution of employment growth rates over the period under study, both on aggregate and comparing SMEs and LEs. For the period 1988-2007, the average employment growth rate across all firms operating in the Portuguese manufacturing industry was $0.33 \%$. SMEs' employment grew on average $0.35 \%$, compared to a growth rate of $0.28 \%$ among LEs. The differences were rarely statistically significant, except for the years 19911993 and 2007, where the differences in employment growth between SMEs and LEs were significant at $1 \%$ level. The negative impact of cyclical recessions on firms' employment growth is evident for both groups: large firms registered negative growth rates during and after slowdown periods and SMEs also suffered considerable job losses.

\section{***Figures 2 and 3 about here***}

As mentioned earlier, differences between small and domestic firms may well be related to the differences that have been systematically found between them. Table 2 provides a brief comparison between SMEs and LEs over the period under study. At the firm level, the statistics reveal that LEs are often more productive, also presenting higher levels of human capital and being more concentrated in urban regions. Additionally, we see that foreign-owned firms are more frequently found among larger enterprises. These differences in performance, human capital, urban location and foreign ownership were always statistically significant at $1 \%$ level for all the years under study. Regarding the industries' specificities, SMEs seem to be concentrated in industries with lower minimum efficient scale, higher employment agglomeration, slower growth and with less presence of foreign firms. Industry-level differences between SMEs and LEs, namely regarding minimum efficient scale, employment agglomeration, concentration and foreign presence were significant at $1 \%$ level for all years. Differences at export intensity of the industries were only relatively significant until the early 2000s. Differences in industry growth were rarely statistically significant.

Regarding the divergences found between SMEs and LEs at these firm-level and industry-level characteristics, we will account for them in our empirical analysis, as they may interfere with the pure effect of firm size on a firm's adjustment abilities during and after a crisis. The correlation coefficients among all these control variables are low and no serious collinearity problems were detected in our estimations.

$* * *$ Table 2 about here $* * *$ 


\subsection{Empirical results}

We started by estimating equation (1) for all firms, for the period 1988-2007, as a baseline case used mainly for comparison with the central results for the separate groups of SMEs and LEs. In Appendix C, we report these first baseline results. Model 1 reports the unconditional effect of firm size upon employment growth. In Model 2 we control for other firm-specific characteristics, such as age, operational performance, ownership, human capital and location. Model 3 inserts the effect of downturn periods. Industry-specificities are inserted in Model 4. The interaction term Size*Downturn, inserted in Models 5 and 6, allowed us to test the effect of firm size upon firm growth during these downturns.

As far as our focal issues, the results obtained suggest that a negative and highly significant effect was exerted by the cyclical economic declines, as firms in general registered about $1 \%$ less employment growth during these periods (Model 4). The interaction term inserted in models 5 and 6 yielded a negative and very significant coefficient. By including this interaction term in the estimations, the effect of downturn alone loses significance, suggesting that the potentially different effect of downturns through firm size may matter most than the downturn effect per se. The coefficient $\gamma_{2}$ may be interpreted as the elasticity of firm size upon firm employment growth during downturns and its negative sign suggests that larger firms have suffered the negative effects of recessive periods more intensely. In other words, employment at smaller firms was apparently less affected by the economic downturns, refuting the hypothesis raised in section 2 .

Although not being the primary focus of our research, our results also identify firm and industry determinants of firm growth over the 20-year period under analysis. We conclude that a non-linear inverted U-shaped relationship between firm size and firm growth exists, which means that smaller firms tend to grow more as they become larger, while very large firms have declining employment growth for an additional unitary increase in their average size. This non-linear relation remains significant throughout the models, even after controlling for other firm and industry's characteristics. Regarding age, a U-shaped relationship with employment growth is found, suggesting that during the firms' infancy the patterns of firm growth appear to be declining, due to the well-known liability of newness and the associated scarce experience in the market. However, as firms become mature, a positive employment growth pattern tends to arise. Regarding the other firm's characteristics, we conclude that more productive firms and firms with higher human capital intensities tend to have lower employment growth levels. The coefficient of firm performance can be interpreted as an elasticity and that of human capital as a semi-elasticity. Firm location in urban centers and the participation of foreign capital do not seem to matter for firm growth. These results seem to be in line with some empirical evidence already established for other economies (see, for instance, Coad 2009). As regards the industries' attributes, we conclude that firms operating in industries with higher MES, less concentrated, more export-intensive, and with higher employment agglomeration have, on average, higher employment growth rates. Firms in industries with a higher share of foreign presence registered, on average, lower growth. In any case, the inclusion of industry-specific variables does little to improve the overall explanatory power and the goodness-of-fit of the regressions (as the adjusted $\mathrm{R}^{2}$ confirms), which is frequently found in other studies on firm growth (e.g., Coad 2009; Short et al. 2009). 
In Table 3 we report the results of our baseline model (reduced version of equation (1), that is, without the interaction term Size*Downturn) for separate groups, i.e. for SMEs (models SME.1 and SME.2) and for LEs (models LE.3 and LE.4). The results provide a robustness check of the previous conclusions raised by baseline results on the different impact of downturn periods upon firms of different sizes. Both groups of firms were significantly negatively affected by economic slowdowns, but larger firms seem to have suffered larger reductions in average employment growth - about 3\% against approximately $1 \%$ for SMEs.

\section{***Table 3 about here $* * *$}

Next, we estimated equation (2), where we focus on the firm size effect upon firm employment growth immediately after the downturn periods. The results for all firms (in the Appendix D) show that the effect of an economic downturn tends to vanish as time goes by - the negative effect of downturns falls from a $2 \%$ reduction in firm growth one year after the beginning of the economic slowdowns to less than $1 \%$ three years later. The inclusion of the interaction term Size*Lagged_Downturn confirms that in the years immediately after the downturns, larger firms also seem to be more affected in terms of growth than smaller firms (the associated coefficient remains negative and significant). The magnitude of the elasticity of size (between -0.0011 and -0.0027) during the recovery periods is lower than during downturns (-0.0056 from Model 6 in Appendix C), but still remarkable.

Table 4 reports the results evaluating the lagged effect of the downturn dummy on each group of firms. The negative effect of downturn periods in the two first years after the downturn was significantly higher for LEs. One year after the recessions LEs showed on average 3.8\% lower employment growth, while SMEs suffered an average decline of $2 \%$. Two years later LEs still suffered on average $2.8 \%$ lower employment growth than during stable economic conditions. For SMEs, the negative effect of downturns was still close to $2 \%$. Three years later, the detrimental effect of the past downturn seems to have faded for LEs, while SMEs still presented about $0.7 \%$ lower growth. In summary, we conclude that the negative effects of downturn periods tend to decrease and vanish over time and that, moreover, LEs, despite being more severely affected by recessive periods, seem to recover more quickly than their smaller counterparts.

\footnotetext{
$* * *$ Table 4 about here $* * *$
}

In conclusion, the results support the idea that SMEs can act as stabilizer agents during economic slowdowns, compared to larger enterprises. LEs tend to suffer larger lay-offs both during and after slowdowns, through being able to quickly recover their stability. Although not being the primary focus of our research, our results also identify firm and industry determinants of firm growth over the $20^{-}$year period under analysis. 


\section{CONCLUSION AND DISCUSSION}

In this paper we have addressed an important, timely and still scarcely explored question. In particular, we also fill a useful niche in the literature, namely better understanding the growth of smaller versus larger firms during moderate macroeconomic downturns. Available firm-level studies on these matters are still scarce and inconclusive, and focus strongly on the Asian financial crisis while rarely providing a comparative analysis of smaller and larger firms. Thus further research is needed on these issues. Our study's contribution extends a prominent discussion to a new context, thereby helping establish the generalizability and boundary conditions of prior knowledge.

We provide evidence on the size-growth relationship by using an empirical setting different to the Asian financial crisis, where the great majority of empirical evidence has been focused. Our study relied on a single-country sample because the required data is rare. Our results are based on the Portuguese case where a (rare) long time microeconomic panel is available. From the best of our knowledge, no previous study has explored the relationship between firm size and firm growth during a crisis event in Portugal. To study the effect of size is a relevant aspect in this context, taking into consideration that the SME sector has always had a very significant position in the Portuguese economy, accounting for a great majority of jobs and almost half of manufacturing turnover. Considering that this business structure is a common feature of many European economies, the results and this study may be of value to other contexts. Although there are benefits to examining Portuguese data, there are inherent socio-economic differences that may limit generalizations to other settings.

In our analysis we identified a long-term trend towards a greater share of SMEs in the number of enterprises and employment. At a time when larger manufacturing companies are outsourcing production to countries outside Europe, one may expect a continuous increase in this share in the future.

Our analysis showed that the recessions identified in the Portuguese economy during the period 1988-2007 had a negative impact on firms' employment growth. After controlling for several firms' and industries' characteristics, employment at smaller firms seems to have been relatively less affected by the economic downturns. During the economic recessions, large enterprises quickly reduced employment. SMEs in affected sectors also acted quickly, but they do not seem to have reduced employment as abruptly as many large companies. There are a number of reasons why Portuguese SMEs may have reacted differently to large enterprises in cyclical downturns. First, it was probably difficult for Portuguese SMEs to downsize employment as they were already small. Second, as SMEs in Portugal typically have lower wages than those in larger enterprises, the need to cut employment during economic slowdowns was lower. Third, as many SMEs are family-based they probably did not want to cut down on employment. Moreover, these firms can use other means to control labor costs in downturns. Specifically, the family members active in the firm are more likely to accept a salary cut. Along these lines we may argue that their wage structure is thus more elastic to demand. In contrast, large enterprises had few options other than to cut off employment. Our results also revealed that the recovery is proportionally more pronounced in large enterprises than in SMEs, probably because they have cut output and employment more than SMEs. 
Taking into consideration the increasing presence of SMEs in the economy as well as the fact that SMEs may act as cushions in downturns, easing the adverse implications for employment, the increasing concern of academics, practitioners and government alike with the SME sector is justified. At the center of the current debate is the need to support SMEs during the crisis. Policy responses to cyclical downturns tend to focus on the financial fragility of SMEs. But, according to the literature, short-term and cyclical financial support to SMEs does not tend to be an effective tool (Storey 1998; Storey and Potter 2008). Indeed, support often tends to come too late to have the intended effect on companies, and many forms of support may have a market-distorting effect. Effective support for SMEs should rather focus on creating and developing long-term structures that facilitate growth and expansion of SMEs, policies promoting SMEs' capabilities and competencies, as well as market structures with competitive SMEs.

Future research could build on our findings and examine the differences in the type of resources that lead to superior resilience of smaller firms during crises compared to larger ones. Also, past lessons may be of value in understanding more modern recessions, such as the present one. Future research could build on our findings and examine the current crises. What complicates this analysis, however, is that not all recessions have the same effects. Recessions such as the current one, which is caused by or associated with financial and banking turbulence, can have disproportionately negative impacts on SMEs. Small businesses are more sensitive to changes in financial conditions (European Commission 2009). Indicators such as the number of bankruptcies in Portugal suggest that this recession is having a more pronounced effect on SMEs than a normal cyclical recession would. However, it is still too early to tell what proportions this will take.

\section{Acknowledgements}

We acknowledge GEP for allowing the use of the original data. The data analysis, results and conclusions are of the authors' own responsibility. GEP stands for Gabinete de Estratégia e Planeamento from MTSS (Ministério do Trabalho e da Solidariedade Social - Ministry of Labour and Social Solidarity). The first author acknowledges the Sabbatical Grant from the Portuguese Fundação para a Ciência e Tecnologia (FCT) [SFRH/S=BSAB/ 920/2009]. 


\section{REFERENCES}

Almus, M. (2002). What characterizes a fast-growing firm?. Applied Economics, 34, 1497-1508.

Álvarez, R. \& Görg, H. (2007). Multinationals as stabilizers?: economic crisis and plant employment growth. Central Bank of Chile, Working Paper No. 412.

Audretsch, D. (1995). Innovation, growth and survival. International Journal of Industrial Organization, $13,441-457$.

Audretsch, D. B., Carree, M. A., van Stel, A. J. \& Thurik, A. R. (2002). Impeded industrial restructuring: the growth penalty. Kyklos, 55, 81-98.

Bank of Portugal (2009a). A Economia Portuguesa em 2008. Economic Bulletin, Spring.

Bank of Portugal (2009b). Perspectivas para a Economia Portuguesa: 2009-2011. Economic Bulletin, Winter.

Barbosa, N. \& Louri, H. (2005). Corporate performance: does ownership matter? A comparison of foreign- and domestic-owned firms in Greece and Portugal. Review of Industrial Organization, 27(1), 73102.

Beck, T., Demirgüç-Kunt, A. \& Maksimovic, V. (2005). Financial and legal constraints to growth: does firm size matter?. The Journal of Finance, 60(1), 137-177.

Berry, A., Rodriguez, E. \& Sandee, H. (2001). Small and medium enterprise dynamics in Indonesia. Bulletin of Indonesian Economic Studies, 37(3), 363-8.

Butler, J. \& Sullivan, J. (2005). Crisis response tactics: U.S. SMEs' responses to the Asian financial crisis. Journal of Business and Entrepreneurship, 17, 2.

Cardoso, V. (2008). Foreign multinationals and domestic companies in Portugal: are there significant performance gaps?. Master Thesis presented to Faculty of Economics, University of Porto: Portugal.

Claessens, S., Djankov, S. \& Xu, L. (2000). Corporate performance in the East Asian financial crisis. The World Bank Research Observer, 15(1), 23-46.

Coad, A. (2009). The growth of firms: a survey of theories and empirical evidence (New Perspectives on the Modern Corporation). Cheltenham: Edward Elgar Publishing.

Das, K. \& Pradhan, J. (2009). Externally-oriented small and medium enterprises: predicament and possibilities. Munich Personal RePEc Archive, MPRA Paper No. 15522.

Domaç, I. \& Ferri, G. (1999). Did the East Asian crisis disproportionately hit small business in Korea?, Economic Notes, 28(3), 403-429.

Dunne, P. \& Hughes, A. (1994). Age, size, growth and survival: UK companies in the 1980s. Journal of Industrial Economics, 42(2), 115-140. 
Erixon, F. (2009). SMEs in Europe: Taking stock and looking forward. European View, 8, 293-300.

European Commission (2009). European SMEs under pressure. Annual Report on SMEs from EIM Business \& Policy Research.

European Commission (2005). The New SME Definition. User guide and model declaration. European Commission Publications, Enterprise and Industry.

Evans, D. (1987). The relationship between firm growth, size and age: estimates for 100 manufacturing industries. Journal of Industrial Economics, 35(4), 567-581.

Forbes, K. (2002). How do large depreciations affect firm performance?. NBER Working Papers 9095, Cambridge, MA.: National Bureau of Economic Research.

Gertler, M. \& Gilchrist, S. (1994). Monetary policy, business cycles, and the behavior of small manufacturing firms. The Quarterly Journal of Economics, 109(2), 309-340.

Gibrat, R. (1931). Les inequalités économiques. Paris: Sirey.

Girma, S. \& Gong, Y. (2008). Putting people first? Chinese state-owned enterprises' adjustment to globalization. International Journal of Industrial Organization, 26, 573-585.

Greene, W. (2008). Econometric Analysis (6 ${ }^{\text {th }}$ Ed.). New York: Prentice Hall.

Guimarães, P., Figueiredo, O. \& Woodward, D. (2000). Agglomeration and the location of foreign direct investment in Portugal. Journal of Urban Economics, 47, 115-135.

Hawawini, G., Subramanian, V. \& verdin P. (2003). Is performance driven by industry-or firm-specific factors? Strategic Management Journal, 24, 1, 1-16.

Higson, C., Holly, S. \& Kattuman, P. (2002). The cross-sectional dynamics of the US business cycle: 1950-1999. Journal of Economic Dynamics \& Control, 26, 1539-1555.

Hodorogel, R. (2009). The economic crisis and its effects on SMEs. Theoretical and Applied Economics, 5(5), 79-88.

Hult, G., Ketchen Jr., D., Griffith, D., Chabowski, B., Hamman, M., Dykes, B., Pollitte, W. \& Cavusgil, S. (2008). An assessment of the measurement of performance in International Business research. Journal of International Business Studies, 39, 1064-1080.

Karlsson, S., Lundin, N., Sjöholm, F. \& He, P. (2009). Foreign firms and Chinese employment. The World Economy, 31(1), 178-201.

Larsen, K. \& Bjerkeland, K. (2005). Are unexpected loan losses lower for small enterprises than for large enterprises?. Norges Bank, Economic Bulletin Q3, 126-132. 
Marino, L., Lohrke, F., Hill, J., Weaver, K. \& Tambunan, T. (2008). Environmental shocks and SME alliance formation intentions in an emerging economy: evidence from the Asian financial crisis in Indonesia. Entrepreneurship Theory and Practice, 32(1), 157-183.

McAleese, D. \& Counahan, M. (1979). Stickers or snatchers? Employment in multinational corporations during recessions. Oxford Bulletin of Economics and Statistics, 41, 345-358.

Mulhern, A. (1996). Venezuelan small businesses and the economic crisis: reflections from Europe. International Journal of Entrepreneurial Behaviour \& Research, 2(2), 69-81.

Narjoko, D. \& Hill, H. (2007). Winners and losers during a deep economic crisis: firm-level evidence from Indonesian manufacturing. Asian Economic Journal, 21(4), 343-368.

Nugent, J. \& Yhee, S. (2002). Small and medium enterprises in Korea: achievements, constraints and policy issues. Small Business Economics, 18, 85-119.

OCDE (2009). The impact of the global crisis on SME and entrepreneurship financing and policy responses. Centre for Entrepreneurship, SMEs and Local Development, Organization for Economic Cooperation and Development.

Özar, S., Özertan, G. \& Irfanoglu, Z. (2008). Micro and small enterprise growth in Turkey: under the shadow of financial crisis. The Developing Economies, 46(4), 331-362.

Özler, S. \& Taymaz, E. (2004). Does foreign ownership matter for survival and growth? Dynamics of competition and foreign direct investment. Economic Research Center, Working Paper No. 04/06.

Pfaffermayr, M. \& Bellak, C. (2002). Why foreign-owned firms are different: a conceptual framework and empirical evidence for Austria. Hamburg Institute of International Economics, HWWA Discussion Paper No. 115.

Régnier, P. (2005). The East Asian financial crisis in Thailand: distress and resilience of local SMEs. In C. Harvie and B. Lee (Eds.), Sustaining Growth and Performance in East Asia - The role of Small and Medium-Sized Enterprises (pp.148-160). USA: Edward Elgar Publishing, Inc.

Robson, P. A. J. \& Bennett, R.J. (2000). SME growth: the relationship with business advice and external collaboration. Small Business Economics, 15, 193-208.

Sato, Y. (2000). How did the crisis affect small and medium-sized enterprises? From a field Study of the metal-working industry in Java, The Developing Economies, XXXVIII (4), 572-95.

Short, J.C., McKelvie, A., Ketchen Jr, D.J. \& Chandler, G.N. (2009). Firm and industry effects on firms performance: a generalization and extension for new ventures. Strategic Entrepreneurship Journal, 3, 4765. 
Storey, D.J. (1998). Six Steps to Heaven: Evaluating The Impact Of Public Policies To Support Small Businesses In Developed Economies, Working paper no. 59, September 1998 Warwick Business School's Small and Medium-sized Enterprise Centre.

Storey, D.J. \& Potter, J. (2008). OECD Framework for the evaluation of SME and Entrepreneurship Policies and Programmes. Paris: OECD.

Sutton, J. (1997). Gibrat's legacy. Journal of Economic Literature, 35, 40-59.

Tan, H. \& See, H. (2004). Strategic reorientation and responses to the Asian financial crisis: the case of the manufacturing industry in Singapore. Asia Pacific Journal of Management, 21, 189-211.

ter Wengel, J. \& Rodriguez, E. (2006). SME export performance in Indonesia after the crisis. Small Business Economics, 26, 25-37.

Teruel-Carrizosa, M. (2010). Gibrat's law and the learning process. Small Business Economics, 34, 355373.

UEAPME (2009). Restoring confidence for a new start - UEAPME priorities for the Swedish presidency, 3 June.

Varum, C. A., Rocha \& V. C. B. (2010). Do foreign and domestic firms behave any different during economic slowdowns?, International Business Review, doi:10.1016/j.ibusrev.2010.06.001 


\section{Appendix}

A. Variable Definitions

\begin{tabular}{|c|c|c|}
\hline CATEGORY & VARIABLES & DESCRIPTION \\
\hline Dependent & Employment Growth & Ln $\left(\right.$ Employment $\left._{\mathrm{t}}\right)-\mathrm{Ln}\left(\right.$ Employment $\left._{\mathrm{t}-1}\right)$ \\
\hline \multirow{2}{*}{$\begin{array}{c}\text { Main variables } \\
\text { of interest }\end{array}$} & Size*Downturn & Interaction variable between firm size and downturn periods \\
\hline & Size*Lagged_Down & Interaction variable between firm size and lagged downturn periods \\
\hline \multirow{8}{*}{ 㐫 } & Age & Number of years since the entry of the firm ${ }^{1}$ \\
\hline & Age squared & Squared number of years since the entry of the firm \\
\hline & Size & Ln (number of employees) \\
\hline & Size squared & Squared value of Ln (number of employees) \\
\hline & Firm Performance & Measured through the $\log$ of the ratio Turnover $(2005=100) /$ Employment \\
\hline & Human Capital & Ratio Number of workers with a college degree/Total number of workers \\
\hline & Ownership & Dummy $=1$ if, at least, $50 \%$ of the capital is held by foreign investors, 0 otherwise. \\
\hline & Urban & Dummy $=1$ if the firm operates in the districts of Porto or Lisbon and 0 otherwise \\
\hline \multirow{8}{*}{$\begin{array}{c}\text { Other } \\
\text { variables }\end{array}$} & MES & Median of 2-digit industry's employment \\
\hline & HH Index & Herfindhal Index - sum of the squared share of FF in total 2-digit industry's employment \\
\hline & Industry Agglomeration & Share of 2-digit industry's employment in total Manufacturing employment \\
\hline & Foreign Share & Share of FF's employment in total 2-digit industry's employment \\
\hline & Export Intensity & Ratio 2-digit industry Exports/2-digit industry VAB \\
\hline & Industry Growth & Ln (2-digit industry Employment $\mathrm{t})$ - Ln (2-digit industry Employment $\left.\mathrm{t}_{\mathrm{t}-1}\right)$ \\
\hline & Industry Dummies & Dummy $=1$ for each 2-digit industry where the firm operates, 0 otherwise \\
\hline & Downturn & Dummy $=1$ for the years $1991,1992,1993,2001,2002,2003,2007$ and 0 otherwise \\
\hline
\end{tabular}

${ }^{1}$ No data for the foundation year was available before 1994. As a result, for the computation of Firm Age, we proxied the foundation year through the year of admission of the former worker for each firm. 
B. SMEs in the non-financial business economy - EU-27 (2005)

\begin{tabular}{|c|c|c|c|}
\hline & \multicolumn{3}{|c|}{ (\% share of SMEs in national total) } \\
\hline & Nr Enterprises & Nr Persons Employed & Value Added \\
\hline EU-27 & 99.8 & 67.1 & 57.6 \\
\hline $\mathrm{BE}$ & 99.8 & 66.6 & 57.8 \\
\hline BG & 99.7 & 72.6 & 53.2 \\
\hline $\mathrm{CZ}$ & 99.8 & 68.9 & 56.7 \\
\hline DK & 99.7 & 66.0 & 64.8 \\
\hline $\mathrm{DE}$ & 99.5 & 60.6 & 53.2 \\
\hline $\mathrm{EE}$ & 99.6 & 78.1 & 75.1 \\
\hline IE & 99.5 & 67.5 & 58.2 \\
\hline EL & 99.9 & 81.9 & 69.6 \\
\hline ES & 99.9 & 78.7 & 68.5 \\
\hline FR & 99.8 & 61.4 & 54.2 \\
\hline IT & 99.9 & 81.3 & 70.9 \\
\hline $\mathrm{CY}$ & 99.9 & 84.3 & 80.0 \\
\hline LV & 99.7 & 75.6 & 71.1 \\
\hline LT & 99.7 & 72.9 & 58.5 \\
\hline LU & 99.6 & 70.8 & 58.5 \\
\hline $\mathrm{HU}$ & 99.8 & 70.9 & 50.2 \\
\hline NL & 99.7 & 67.6 & 61.5 \\
\hline $\mathrm{AT}$ & 99.7 & 67.4 & 60.0 \\
\hline PL & 99.8 & 69.8 & 48.4 \\
\hline PT & 99.9 & 82.0 & 67.8 \\
\hline RO & 99.5 & 60.8 & 48.4 \\
\hline SI & 99.7 & 66.4 & 60.6 \\
\hline SK & 98.8 & 54.0 & 44.5 \\
\hline FI & 99.7 & 58.5 & 53.9 \\
\hline SE & 99.8 & 63.2 & 55.6 \\
\hline UK & 99.6 & 54.0 & 51.0 \\
\hline NO & 99.8 & 69.6 & 68.6 \\
\hline
\end{tabular}


C. Employment growth estimation results - All Firms

\begin{tabular}{|c|c|c|c|c|c|c|c|c|c|c|c|c|}
\hline \multirow[b]{2}{*}{ Constant } & \multicolumn{2}{|c|}{ Model 1} & \multicolumn{2}{|l|}{ Model 2} & \multicolumn{2}{|c|}{ Model 3} & \multicolumn{2}{|c|}{ Model 4} & \multicolumn{2}{|c|}{ Model 5} & \multicolumn{2}{|c|}{ Model 6} \\
\hline & $\begin{array}{l}-0.8427 \\
(0.0104)\end{array}$ & *** & $\begin{array}{r}0.7017 \\
(0.0128)\end{array}$ & $* * *$ & $\begin{array}{r}0.7074 \\
(0.0132)\end{array}$ & *** & $\begin{array}{r}0.6009 \\
(0.0139)\end{array}$ & $* * *$ & $\begin{array}{r}0.7009 \\
(0.0132)\end{array}$ & $* * *$ & $\begin{array}{r}0.5936 \\
(0.0140)\end{array}$ & *** \\
\hline Age & - & & $\begin{array}{l}-0.0018 \\
(0.0001)\end{array}$ & *** & $\begin{array}{l}-0.0017 \\
(0.0001)\end{array}$ & *** & $\begin{array}{l}-0.0007 \\
(0.0001)\end{array}$ & $* * *$ & $\begin{array}{l}-0.0017 \\
(0.0001)\end{array}$ & *** & $\begin{array}{l}-0.0007 \\
(0.0001)\end{array}$ & $* * *$ \\
\hline $\mathrm{Age}^{2}$ & - & & $\begin{array}{r}8.72 \mathrm{e}-07 \\
(3.22 \mathrm{e}-08)\end{array}$ & $* * *$ & $\begin{array}{r}8.56 \mathrm{e}-07 \\
(3.22 \mathrm{e}-08)\end{array}$ & $* * *$ & $\begin{array}{r}3.67 \mathrm{e}-07 \\
(3.82 \mathrm{e}-08)\end{array}$ & $* * *$ & $\begin{array}{r}8.40 \mathrm{e}-07 \\
(3.23 \mathrm{e}-08)\end{array}$ & *** & $\begin{array}{l}-3.44 \mathrm{e}-07 \\
(3.83 \mathrm{e}-08)\end{array}$ & $* * *$ \\
\hline Size & $\begin{array}{r}0.5326 \\
(0.0019)\end{array}$ & & $\begin{array}{r}0.4589 \\
(0.0020)\end{array}$ & $* * *$ & $\begin{array}{r}0.4589 \\
(0.0020)\end{array}$ & $* * *$ & $\begin{array}{c}0.4594 \\
(0.0020)\end{array}$ & $* * *$ & $\begin{array}{r}0.4609 \\
(0.0020)\end{array}$ & $* * *$ & $\begin{array}{r}0.4615 \\
(0.0020)\end{array}$ & *** \\
\hline $\mathrm{Size}^{2}$ & $\begin{array}{l}-0.0419 \\
(0.0004)\end{array}$ & & $\begin{array}{l}-0.0351 \\
(0.0004)\end{array}$ & $* * *$ & $\begin{array}{r}-0.0350 \\
(0.0004)\end{array}$ & $* * *$ & $\begin{array}{c}-0.0356 \\
(0.0004)\end{array}$ & $* * *$ & $\begin{array}{l}-0.0350 \\
(0.0004)\end{array}$ & $* * *$ & $\begin{array}{l}-0.0356 \\
(0.0004)\end{array}$ & *** \\
\hline Firm Performance & - & & $\begin{array}{l}-0.1378 \\
(0.0007)\end{array}$ & $* * *$ & $\begin{array}{l}-0.1377 \\
(0.0007)\end{array}$ & $* * *$ & $\begin{array}{l}-0.1365 \\
(0.0007)\end{array}$ & $* * *$ & $\begin{array}{l}-0.1377 \\
(0.0007)\end{array}$ & $* * *$ & $\begin{array}{l}-0.1365 \\
(0.0007)\end{array}$ & *** \\
\hline Human Capital & - & & $\begin{array}{l}-0.1659 \\
(0.0082)\end{array}$ & $* * *$ & $\begin{array}{l}-0.1615 \\
(0.0082)\end{array}$ & $* * *$ & $\begin{array}{l}-0.1517 \\
(0.0083)\end{array}$ & $* * *$ & $\begin{array}{l}-0.1603 \\
(0.0082)\end{array}$ & $* * *$ & $\begin{array}{l}-0.1501 \\
(0.0083)\end{array}$ & $* * *$ \\
\hline Ownership & - & & $\begin{array}{l}-0.0088 \\
(0.0062)\end{array}$ & & $\begin{array}{l}-0.0094 \\
(0.0062)\end{array}$ & & $\begin{array}{l}-0.0070 \\
(0.0062)\end{array}$ & & $\begin{array}{l}-0.0097 \\
(0.0062)\end{array}$ & & $\begin{array}{l}-0.0073 \\
(0.0062)\end{array}$ & \\
\hline Urban & - & & $\begin{array}{r}0.0100 \\
(0.0076)\end{array}$ & & $\begin{array}{r}0.0097 \\
(0.0076)\end{array}$ & & $\begin{array}{r}0.0060 \\
(0.0076)\end{array}$ & & $\begin{array}{r}0.0096 \\
(0.0076)\end{array}$ & & $\begin{array}{r}0.0059 \\
(0.0076)\end{array}$ & \\
\hline Downturn & - & & - & & $\begin{array}{l}-0.0096 \\
(0.0008)\end{array}$ & $* * *$ & $\begin{array}{l}-0.0122 \\
(0.0008)\end{array}$ & $* * *$ & $\begin{array}{r}0.0015 \\
(0.0015)\end{array}$ & & $\begin{array}{l}-0.0003 \\
(0.0015)\end{array}$ & \\
\hline Size*Downturn & - & & - & & - & & - & & $\begin{array}{l}-0.0052 \\
(0.0006)\end{array}$ & *** & $\begin{array}{l}-0.0056 \\
(0.0006)\end{array}$ & *** \\
\hline MES & - & & - & & - & & $\begin{array}{r}0.0128 \\
(0.0005)\end{array}$ & $* * *$ & - & & $\begin{array}{r}0.0129 \\
(0.0005)\end{array}$ & $* * *$ \\
\hline HH Index & - & & - & & - & & $\begin{array}{l}-0.4830 \\
(0.2104)\end{array}$ & $* *$ & - & & $\begin{array}{l}-0.5167 \\
(0.2105)\end{array}$ & $* *$ \\
\hline Industry Agglomeration & - & & - & & - & & $\begin{array}{r}0.0908 \\
(0.0320)\end{array}$ & $* * *$ & - & & $\begin{array}{r}0.0881 \\
(0.0320)\end{array}$ & $* * *$ \\
\hline Export Intensity & - & & - & & - & & $\begin{array}{r}0.0048 \\
(0.0014)\end{array}$ & $* * *$ & - & & $\begin{array}{r}0.0045 \\
(0.0014)\end{array}$ & *** \\
\hline Industry Growth & - & & - & & - & & $\begin{array}{r}0.0010 \\
(0.0016)\end{array}$ & & - & & $\begin{array}{r}0.0011 \\
(0.0016)\end{array}$ & \\
\hline Foreign Share & - & & - & & - & & $\begin{array}{l}-0.0658 \\
(0.0228)\end{array}$ & *** & - & & $\begin{array}{l}-0.0662 \\
(0.0228)\end{array}$ & *** \\
\hline Industry Dummies & YES & & YES & & YES & & YES & & YES & & YES & \\
\hline $\mathrm{N}$ & 719217 & & 660461 & & 660461 & & 660457 & & 660461 & & 660457 & \\
\hline $\mathrm{R}^{2}$ Adjusted & 0.2031 & & 0.2748 & & 0.2750 & & 0.2762 & & 0.2751 & & 0.2763 & \\
\hline
\end{tabular}

Fixed Effects panel data estimations with robust standard errors.

$* * *, * *, *$ means significant at $1 \%, 5 \%$ and $10 \%$ level, respectively. 
D. Employment growth estimation results with time lags for downturn periods - All Firms

\begin{tabular}{|c|c|c|c|c|c|c|c|c|c|c|c|c|}
\hline \multirow[b]{3}{*}{ Constant } & \multicolumn{4}{|c|}{ With 1-year lag } & \multicolumn{4}{|c|}{ With 2-year lag } & \multicolumn{4}{|c|}{ With 3-year lag } \\
\hline & \multicolumn{2}{|c|}{ Model 1.1 } & \multicolumn{2}{|c|}{ Model 1.2} & \multicolumn{2}{|c|}{ Model 2.1 } & \multicolumn{2}{|c|}{ Model 2.2} & \multicolumn{2}{|c|}{ Model 3.1} & \multicolumn{2}{|c|}{ Model 3.2 } \\
\hline & 0.6172 & $* * *$ & 0.6167 & $* * *$ & 0.6626 & **** & 0.6617 & $* * *$ & 0.7297 & $* * *$ & 0.7290 & *** \\
\hline & $(0.0261)$ & & $(0.0261)$ & & $(0.0271)$ & & $(0.0271)$ & & $(0.0280)$ & & $(0.0280)$ & \\
\hline \multirow[t]{2}{*}{ Age } & -0.0006 & $* * *$ & -0.0006 & $* * *$ & -0.0006 & $* * *$ & -0.0006 & $* * *$ & -0.0006 & $* * *$ & -0.0006 & $* * *$ \\
\hline & $(0.0001)$ & & $(0.0001)$ & & $(0.0001)$ & & $(0.0001)$ & & $(0.0001)$ & & $(0.0001)$ & \\
\hline \multirow[t]{2}{*}{$\operatorname{Age}^{2}$} & $2.98 \mathrm{e}-07$ & $* * *$ & $2.96 \mathrm{e}-07$ & *** & $2.93 e-07$ & **** & $2.95 \mathrm{e}-07$ & $* * *$ & $2.79 \mathrm{e}-07$ & *** & $2.89 \mathrm{e}-07$ & $* * *$ \\
\hline & $(6.00 \mathrm{e}-08)$ & & $(6.00 \mathrm{e}-08)$ & & $(6.25 \mathrm{e}-08)$ & & $(6.25 \mathrm{e}-08)$ & & $(6.65 \mathrm{e}-08)$ & & $(6.65 e-08)$ & \\
\hline \multirow[t]{2}{*}{ Size } & 0.4638 & $* * *$ & 0.4642 & $* * *$ & 0.4652 & $* * *$ & 0.4662 & $* * *$ & 0.4677 & $* * *$ & 0.4691 & $* * *$ \\
\hline & $(0.0047)$ & & $(0.0047)$ & & $(0.0048)$ & & $(0.0048)$ & & $(0.0050)$ & & $(0.0050)$ & \\
\hline \multirow[t]{2}{*}{$\mathrm{Size}^{2}$} & -0.0355 & $* * *$ & -0.0355 & *** & -0.0346 & $* * *$ & -0.0346 & $* * *$ & -0.0336 & $* * *$ & -0.0338 & $* * *$ \\
\hline & $(0.0011)$ & & $(0.0011)$ & & $(0.0012)$ & & $(0.0012)$ & & $(0.0012)$ & & $(0.0012)$ & \\
\hline \multirow[t]{2}{*}{ Firm Performance } & -0.1399 & **** & -0.1399 & $* * *$ & -0.1450 & $* * *$ & -0.1450 & $* * *$ & -0.1506 & $* * *$ & -0.1506 & $* * *$ \\
\hline & $(0.0019)$ & & $(0.0019)$ & & $(0.0020)$ & & $(0.0020)$ & & $(0.0021)$ & & $(0.0021)$ & \\
\hline \multirow[t]{2}{*}{ Human Capital } & -0.1551 & $* * *$ & -0.1549 & $* * *$ & -0.1568 & $* * *$ & -0.1565 & $* * *$ & -0.1490 & $* * *$ & -0.1488 & $* * *$ \\
\hline & $(0.0204)$ & & $(0.0204)$ & & $(0.0203)$ & & $(0.0203)$ & & $(0.0201)$ & & $(0.0201)$ & \\
\hline \multirow[t]{2}{*}{ Ownership } & -0.0077 & & -0.0078 & & -0.0075 & & -0.0072 & & -0.0090 & & -0.0086 & \\
\hline & $(0.0093)$ & & $(0.0093)$ & & $(0.0096)$ & & $(0.0096)$ & & $(0.0100)$ & & $(0.0100)$ & \\
\hline \multirow[t]{2}{*}{ Urban } & 0.0065 & & 0.0064 & & 0.0082 & & 0.0080 & & 0.0066 & & 0.0065 & \\
\hline & $(0.0147)$ & & $(0.0147)$ & & $(0.0150)$ & & $(0.0150)$ & & $(0.0153)$ & & $(0.0153)$ & \\
\hline \multirow[t]{2}{*}{ Lagged_Downturn } & -0.0204 & $* * *$ & -0.0180 & $* * *$ & -0.0191 & $* * *$ & -0.0141 & $* * *$ & -0.0073 & $* * *$ & -0.0017 & \\
\hline & $(0.0008)$ & & $(0.0018)$ & & $(0.0009)$ & & $(0.0018)$ & & $(0.0008)$ & & $(0.0018)$ & \\
\hline \multirow[t]{2}{*}{ Size*Lagged_Downturn } & - & & -0.0011 & $*$ & - & & -0.0024 & $* * *$ & - & & -0.0027 & $* * *$ \\
\hline & & & $(0.0007)$ & & & & $(0.0007)$ & & & & $(0.0007)$ & \\
\hline \multirow[t]{2}{*}{ MES } & 0.0108 & $* * *$ & 0.0108 & $* * *$ & 0.0094 & $* * *$ & 0.0094 & $* * *$ & 0.0057 & $* * *$ & 0.0057 & $* * *$ \\
\hline & $(0.0007)$ & & $(0.0007)$ & & $(0.0008)$ & & $(0.0008)$ & & $(0.0008)$ & & $(0.0008)$ & \\
\hline \multirow[t]{2}{*}{ HH Index } & -0.6627 & $* *$ & -0.6722 & $* *$ & -0.7380 & $* *$ & -0.7671 & $* *$ & -0.0259 & & -0.0675 & \\
\hline & $(0.3107)$ & & $(0.3107)$ & & $(0.3657)$ & & $(0.3657)$ & & $(0.4072)$ & & $(0.4072)$ & \\
\hline \multirow[t]{2}{*}{ Industry Agglomeration } & 0.1540 & $* * *$ & 0.1535 & $* * *$ & 0.1422 & $* * *$ & 0.1388 & $* * *$ & 0.2146 & $* * *$ & 0.2096 & $* * *$ \\
\hline & $(0.0399)$ & & $(0.0399)$ & & $(0.0405)$ & & $(0.0405)$ & & $(0.0411)$ & & $(0.0411)$ & \\
\hline Export Intensity & -0.0023 & & -0.0024 & & -0.0063 & $* * *$ & -0.0063 & $* * *$ & -0.0009 & & -0.0007 & \\
\hline & $(0.0017)$ & & $(0.0017)$ & & $(0.0018)$ & & $(0.0018)$ & & $(0.0018)$ & & $(0.0018)$ & \\
\hline Industry Growth & -0.0001 & & -0.0001 & & -0.0013 & & -0.0013 & & 0.0005 & & 0.0005 & \\
\hline & $(0.0017)$ & & $(0.0017)$ & & $(0.0017)$ & & $(0.0017)$ & & $(0.0017)$ & & $(0.0017)$ & \\
\hline Foreign Share & -0.0033 & & -0.0039 & & 0.1590 & $* * *$ & 0.1594 & $* * *$ & 0.0053 & & 0.0078 & \\
\hline & $(0.0246)$ & & $(0.0246)$ & & $(0.0264)$ & & $(0.0264)$ & & $(0.0259)$ & & $(0.0259)$ & \\
\hline Industry Dummies & YES & & YES & & YES & & YES & & YES & & YES & \\
\hline $\mathrm{N}$ & 637417 & & 637417 & & 612152 & & 612152 & & 586355 & & 586355 & \\
\hline $\mathrm{R}^{2}$ Adjusted & 0.2822 & & 0.2822 & & 0.2888 & & 0.2888 & & 0.2954 & & 0.2954 & \\
\hline
\end{tabular}

Fixed Effects panel data estimations with robust standard errors.

$* * *, * *, *$ means significant at $1 \%, 5 \%$ and $10 \%$ level, respectively. 